\title{
Synthesis of 1,5-Benzodiazepine and Its Derivatives by Condensation Reaction Using H-MCM-22 as Catalyst
}

\author{
Sheikh Abdul Majid, Waheed Ahmad Khanday, and Radha Tomar \\ S.O.S in Chemistry, Jiwaji University, Gwalior 474011, India
}

Correspondence should be addressed to Radha Tomar, radha_tomar11@yahoo.co.in

Received 2 December 2011; Revised 24 January 2012; Accepted 7 February 2012

Academic Editor: Daehee Kang

Copyright (C) 2012 Sheikh Abdul Majid et al. This is an open access article distributed under the Creative Commons Attribution License, which permits unrestricted use, distribution, and reproduction in any medium, provided the original work is properly cited.

A simple and versatile method for the synthesis of 1,5-benzodiazepines is via condensation of o-phenylenediamines (OPDA) and ketones in the presence of catalytic amount of H-MCM-22 using acetonitrile as solvent at room temperature. In all the cases, the reactions are highly selective and are completed within $1-3 \mathrm{~h}$. The method is applicable to both cyclic and acyclic ketones without significant differences. The reaction proceeds efficiently under ambient conditions with good-to-excellent yields.

\section{Introduction}

Benzodiazepines constitute an important class of biologically active compounds and their synthesis has been receiving much attention in the field of medicinal and pharmaceutical chemistry owing to their application as anticonvulsant, antiinflammatory, analgesic, hypnotic, and sedative agents and to their hypnotic activity [1-6]. The derivatives of 1,5benzodiazepines are also used as dyes for acrylic fibers in photography [7]. In addition, benzodiazepines are the useful precursors for the synthesis of other fused ring compounds such as triazolo-, oxadiazolo-, oxazino-, or furano-benzodiazepines [8-11]. Benzodiazepines are generally synthesized by the condensation of o-phenylenediamine (OPDA) with a,b-unsaturated carbonyl compounds, b-haloketones, or with ketones [12] using acidic catalysts which are critical to enhance the condensation process. Different reagents such as $\mathrm{BF}_{3}$-etherate, polyphosphoric acid, $\mathrm{NaBH}_{4}, \mathrm{MgO} / \mathrm{POCl}_{3}$, $\mathrm{Yb}(\mathrm{OTf})_{3}, \mathrm{Ga}(\mathrm{OTf})_{3}$, lead nitrate, L-proline, acetic acid under microwave conditions, molecular iodine, and ionic liquids have also been used for the synthesis of benzodiazepines [13-23]. Recently the synthesis of benzodiazepines has also been reported using different solid acid catalysts such as sulfated zirconia, $\mathrm{Al}_{2} \mathrm{O}_{3} / \mathrm{P}_{2} \mathrm{O}_{5}, \mathrm{Ag}_{3} \mathrm{PW}_{12} \mathrm{O}_{40}$, PVP$\mathrm{FeCl}_{3}$, and zeolite catalysts [24-28]. Unfortunately, many of these catalysts suffer from one or more limitations, such as long reaction times, occurrence of several side reactions, drastic reaction conditions, low yields, and tedious workup procedure. In addition, the solid oxide catalyst used previously had poor textural parameters such as low surface area and pore volume which do not support a better performance in the synthesis of benzodiazepines. These factors stimulate the search for a better catalyst, which should offer a high activity for the synthesis of 1,5-benzodiazepines under mild reaction conditions. In recent years, mesoporous materials with different structure and tunable pore diameters have been receiving much attention.

Here we demonstrate, the synthesis of 1,5-benzodiazepine using H-MCM-22 as catalyst through a condensation reaction between OPDA and ketones in acetonitrile condition. The effect of catalyst and the catalyst concentration on the above process has been investigated in detail.

\section{Experimental Section}

2.1. Synthesis of Catalysts Synthesis of (H-MCM-22). The hydrothermal synthesis of layered aluminosilicate MCM22 was carried out by using hexamethyleneimine as an organic template at dynamic conditions. A total of $3.110 \mathrm{~g}$ of anhydrous sodium aluminate $\left(50-56 \% \mathrm{Al}_{2} \mathrm{O}_{3}\right.$, maximum $0.05 \% \mathrm{Fe}_{2} \mathrm{O}_{3}, 40-45 \% \mathrm{Na}_{2} \mathrm{O}$, purchased from RiedeldeHaën) and $1.930 \mathrm{~g}$ of sodium hydroxide (97\%, from Merck) was dissolved in $415 \mathrm{~g}$ of deionized water. The 


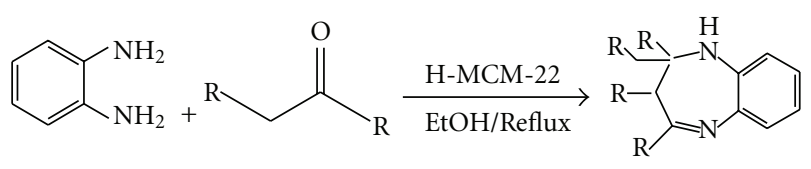

Scheme 1: Synthesis of 1,5-benzodiazepines using H-MCM-22 catalysts at room temperature.

solution was thoroughly stirred for 15 minutes, and then $25.4 \mathrm{~g}$ of hexamethyleneimine (HMI) (99\%, from Aldrich) was added dropwise with vigorous stirring. To this, $30.7 \mathrm{~g}$ of silica (Aerosil 200, Degussa) was added in small portions and the resulting slurry continued to be stirred vigorously. After 30 minutes of stirring, at room temperature, a gel was formed; this was then placed in an autoclave and heated at $150^{\circ} \mathrm{C}$ for 10 days. After immersing the autoclaves in cold water, the resulting material was washed and centrifuged until $\mathrm{pH} \leq 9$ and subsequently dried at $70^{\circ} \mathrm{C}$. A 1-gram sample of MCM-22 was calcined in the absence of air at $650^{\circ} \mathrm{C}$ for 7 hours, generating Na-MCM-22 zeolite. The process took place in an oven in order to remove water and organic precursor. The oven was programmed at a heating rate of $5^{\circ} \mathrm{C} / \mathrm{min}$ until $650^{\circ} \mathrm{C}$ for $7 \mathrm{~h}$. The Na-MCM- 22 zeolite is converted into the $\mathrm{H}$-form by the following procedure: $9.000 \mathrm{~g}$ of $\mathrm{Na}-\mathrm{MCM}-22,7.230 \mathrm{~g}$ of $\mathrm{NH}_{4} \mathrm{Cl}$, and $13.80 \mathrm{~mL}$ of deionized water were mixed with $0.1 \mathrm{M}$ hydrochloric acid solution, in order to reach $\mathrm{pH}$ 4.0. The mixture was stirred at $60^{\circ} \mathrm{C}$ for $30 \mathrm{~min}$. Then the material was filtered under suction and washed with deionized water. After the removal of chlorides, the resulting material, $\mathrm{NH}_{4}-\mathrm{MCM}-22$ zeolite, was placed in an oven at $60^{\circ} \mathrm{C}$ for $24 \mathrm{~h}$. The ammonium form of MCM-22 was converted into $\mathrm{H}$-form by calcination over $60 \mathrm{~min}$ at $200^{\circ} \mathrm{C}$.

2.2. Characterization of the Catalysts and the Products. XRay Diffraction (XRD): the samples were sieved in an ABNT $\mathrm{n}^{\circ} 200(0.074 \mathrm{~mm})$ sieve and then placed in an aluminum sample holder for X-ray diffraction assays, using a Shimadzu XRD 6000 equipment. The operational details of the technique were set as follows: copper $\mathrm{K} \alpha$ radiation at $40 \mathrm{KV} / 30 \mathrm{~mA}$, with a goniometer speed of $2^{\circ} / \mathrm{min}$ and a step of $0.02^{\circ}$ in the $2 \theta$ range scanning from $2^{\circ}$ to $50^{\circ}$. The only $\mathrm{d}$-spacings of interest in the X-ray patterns were the basal spacings along the $c$ axis.

Fourier-transform infrared (FT-IR) spectroscopy: the MCM-22 sample was submitted to physical treatment in accordance with the $\mathrm{KBr}$ method, which consists of mixing $0.007 \mathrm{~g}$ of the sample and $0.1 \mathrm{~g}$ of $\mathrm{KBr}$, grinding and pressing the solid mixture to 5 ton for $30 \mathrm{~s}$ in order to form a pastille that allows the passage of light. Characterization was performed using an infrared spectrophotometer SHIMADZU FT-IR in the wavelength ranges from 2000 to $400 \mathrm{~cm}^{-1}$, with increments of $650 \mathrm{~cm}^{-1}$ and a resolution of $4 \mathrm{~cm}^{-1}$.

Characterization of the product was performed on SHIMADZU FT-IR spectrometer, and the sample was prepared with $\mathrm{KBr}$ and pressed into wafer/pellet. Spectra were collected in the range of $400-4000 \mathrm{~cm}^{-1}$. NMR of the products was performed on BRUKER ADVANCE II 300 NMR spectrometer.
Gas chromatography for benzodiazepine was performed using Younglin gas chromatograph (YL6100 GC). A narrowbore capillary column $(25 \mathrm{~m} \times 0.22$ with $0.25 \mu \mathrm{m}$ thickness $)$ was used and an oven temperature of $250^{\circ} \mathrm{C}$ was employed with injector and detector temperature of $275^{\circ} \mathrm{C}$. Yield was calculated from the peak area

$$
\text { Area }=\text { Height of peak } \times \text { Width at half-height, }
$$

and $\%$ yield was calculated as

$$
\% \text { yield }=\frac{\text { Area of component }}{\text { Total area }} \times 100
$$

2.3. Synthesis of 1,5-Benzodiazepine. A mixture of OPDA (1 mmol, $108.1 \mathrm{mg})$, ketone $(2.5 \mathrm{mmol}, 145.2 \mathrm{mg})$, and $\mathrm{H}$ MCM-22 (100 mg) was stirred in acetonitrile $(4 \mathrm{~mL})$ at room temperature until thin layer chromatography indicated the reaction was completed (as shown in Scheme 1). Ethyl acetate $(10 \%)$ in hexane was used as the mobile phase and both the reactant and the final product were spotted on the TLC plate. The product retention factor (Rf) was observed at 0.4. The disappearance of the reactant spot on the TLC place indicates the completion of the reaction. After completion of the reaction, ethyl acetate $(20 \mathrm{~mL})$ was added to the reaction mixture and the catalyst was recovered by filtration. The organic layer was concentrated and the crude product was purified by silica gel column chromatography using ethyl acetate: n-hexane $(1: 9)$ as eluent to afford the desired product.

Entry 1 (2a). Yellow solid; m.p. $137-139^{\circ} \mathrm{C}$ FT-IR (KBr): $v_{\max }\left(\right.$ in $\mathrm{Cm}^{-1}$ ) 3362, 1501, 1474; $1 \mathrm{H}$ NMR $(300 \mathrm{MHz}$, $\left.\mathrm{CDCl}_{3}\right): \delta(\mathrm{ppm}): 7-7.25(\mathrm{~m}, 4 \mathrm{H}, \mathrm{Ar}-\mathrm{H}), 2.90-2.95(\mathrm{~d}, 1 \mathrm{H}$, $\mathrm{CH}), 3.90-4.25\left(\mathrm{~m}, 2 \mathrm{H}, \mathrm{CH}_{2}\right), 3.5$ (br s, $\left.1 \mathrm{H}, \mathrm{NH}\right), 3(\mathrm{~s}, 2 \mathrm{H}, \mathrm{N}$ $\left.=\mathrm{C}-\mathrm{CH}_{2}\right), 2.5\left(\mathrm{~m}, 3 \mathrm{H}, \mathrm{N}=\mathrm{C}-\mathrm{CH}_{3}\right), 1.50-1.75\left(\mathrm{~s}, 6 \mathrm{H}, 2 \mathrm{CH}_{3}\right)$.

Entry 2 (2b). Yellow solid; m.p. $137-139^{\circ} \mathrm{C}$; FT-IR (KBr): $v_{\max }\left(\right.$ in $\left.\mathrm{Cm}^{-1}\right) 3329,1637,1605 ; 1 \mathrm{H}$ NMR $(300 \mathrm{MHz}$, $\left.\mathrm{CDCl}_{3}\right): \delta(\mathrm{ppm}): 0.99(\mathrm{t}, 3 \mathrm{H}, J=6.9 \mathrm{~Hz}), 1.25(\mathrm{t}, 3 \mathrm{H}, J=$ $6.9 \mathrm{~Hz}), 1.70(\mathrm{q}, 2 \mathrm{H}, J=6.9 \mathrm{~Hz}) 2.15(\mathrm{~m}, 2 \mathrm{H}), 2.35(\mathrm{~s}, 3 \mathrm{H})$, $2.69(\mathrm{q}, 2 \mathrm{H}, J=6.9 \mathrm{~Hz}), 3.25(\mathrm{br} \mathrm{s}, 1 \mathrm{H}, \mathrm{NH}), 6.78-7.35(\mathrm{~m}$, $4 \mathrm{H}) ; 13 \mathrm{C}$ NMR $\left(50 \mathrm{MHz}, \mathrm{CDCl}_{3}\right) \delta(\mathrm{ppm}): 8.7,10.6,26.9$, $35.5,35.7,42.0,70.7,121.7,125.2,126.2,27.1,138.0,140.9$, 175.5 .

Entry 3 (2c). Yellow solid; m.p. $151-152^{\circ} \mathrm{C}$; FT-IR (KBr): $v_{\max }\left(\right.$ in $\left.\mathrm{Cm}^{-1}\right) 3330,1635 ; 1 \mathrm{H} \mathrm{NMR}\left(300 \mathrm{MHz}, \mathrm{CDCl}_{3}\right): \delta$ (ppm): $1.80(\mathrm{~s}, 3 \mathrm{H}), 2.95(\mathrm{~d}, 1 \mathrm{H}, J=12.8 \mathrm{~Hz}), 3.15(\mathrm{~d}, 1 \mathrm{H}$, $J=12.8 \mathrm{~Hz}) 3.45(\mathrm{br} \mathrm{s}, \mathrm{NH}), 6.55-7.0(\mathrm{~m}, 3 \mathrm{H}), 7.15-7.35$ (m, 7H), 7.55-7.65 (m, 4H); 13C NMR (50 MHz, $\left.\mathrm{CDCl}_{3}\right)$ $\delta(\mathrm{ppm}): 167.5,146.6,140.1,139.5,138.2,129.8,128.6,128.4$, 
$128.1,127.4,127.1,126.4,125.5,121.7,121.5,73.9,43.0$, 29.9 .

Entry 4 (2d). Yellow solid; m.p $164-165^{\circ} \mathrm{C}$, FT-IR (KBr): $v_{\max }\left(\right.$ in $\left.\mathrm{Cm}^{-1}\right): 3375 ; 1 \mathrm{H} \mathrm{NMR}\left(300 \mathrm{MHz}, \mathrm{CDCl}_{3}\right): \delta$ (ppm): $1.48-1.84(\mathrm{~m}, 10 \mathrm{H}), 4.15$ (br s, $1 \mathrm{H}, \mathrm{NH}), 4.69$ (br s, $1 \mathrm{H}, \mathrm{NH}), 6.37(\mathrm{~d}, 2 \mathrm{H}), 7.71(\mathrm{~d}, \mathrm{~d}, 2 \mathrm{H}) .13 \mathrm{C}$ NMR $\left(50 \mathrm{MHz}, \mathrm{CDCl}_{3}\right): d=23.50,25.04,39.83,82.15,103.35$, $104.84,119.80,132.35,140.62,146.20$.

Entry 5 (2e). Yellow solid; m.p. $156-158^{\circ} \mathrm{C}$, FT-IR (KBr): $v_{\max }\left(\right.$ in $\left.\mathrm{Cm}^{-1}\right): 3344,1647,1603.1 \mathrm{H} \mathrm{NMR}(300 \mathrm{MHz}$, $\left.\mathrm{CDCl}_{3}\right): \delta(\mathrm{ppm}): 1.88-2.10\left(\mathrm{~m}, 12 \mathrm{H}, 6 \mathrm{CH}_{2}\right), 2.90-2.95(\mathrm{~d}$, $1 \mathrm{H}, \mathrm{CH}), 3.90-4.25\left(\mathrm{~m}, 2 \mathrm{H}, \mathrm{CH}_{2}\right), 3.05$ (br s, $\left.1 \mathrm{H}, \mathrm{NH}\right), 6.63-$ $6.64(\mathrm{~m}, 1 \mathrm{H}, \mathrm{Ar}-\mathrm{H}), 6.73-6.77(\mathrm{~m}, 1 \mathrm{H}, \mathrm{Ar}-\mathrm{H}), 7.87-7.90(\mathrm{~m}$, $1 \mathrm{H}, \mathrm{Ar}-\mathrm{H})$.

Entry 6 (2f). Yellow solid, m.p. $94-96^{\circ} \mathrm{C}, \mathrm{IR}(\mathrm{KBr})$ : $\operatorname{mmax}$ $3424,1595,1499 \mathrm{~cm}^{-1}$. 1H NMR $\left(300 \mathrm{MHz}, \mathrm{CDCl}_{3}\right): \mathrm{d} 0.93$ (t, $\left.3 \mathrm{H}, \mathrm{CH}_{3}\right), 1.24-1.25\left(\mathrm{~m}, 6 \mathrm{H}, 2 \mathrm{CH}_{3}\right), 1.60-1.65(\mathrm{~m}, 2 \mathrm{H}$, $\left.\mathrm{CH}_{2}\right), 2.22\left(\mathrm{~m}, 2 \mathrm{H}, \mathrm{CH}_{2}\right), 2.50-2.68(\mathrm{q}, 2 \mathrm{H}, J=3.23 \mathrm{~Hz}$, $\left.\mathrm{CH}_{2}\right), 3.00-3.20$ (br s, $\left.1 \mathrm{H}, \mathrm{NH}\right), 6.62-6.71(\mathrm{~m}, 1 \mathrm{H}, \mathrm{Ar}-\mathrm{H})$, 6.88-6.93 (m, 1H, Ar-H), 7.04-7.14 (m, 1H, Ar-H).

Entry 7 (2g). Pale yellow solid, m.p. $138-140^{\circ} \mathrm{C}, \mathrm{IR}(\mathrm{KBr})$ : $\operatorname{mmax} 3320,1602,1567 \mathrm{~cm}^{-1}$. $1 \mathrm{H} \mathrm{NMR}\left(300 \mathrm{MHz}, \mathrm{CDCl}_{3}\right)$ : d $1.72\left(\mathrm{~s}, 3 \mathrm{H}, \mathrm{CH}_{3}\right), 2.17\left(\mathrm{~s}, 2 \mathrm{H}, \mathrm{CH}_{2}\right), 2.33\left(\mathrm{~s}, 6 \mathrm{H}, 2 \mathrm{CH}_{3}\right)$ 3.00 (br s, $1 \mathrm{H}, \mathrm{NH}), 6.80-6.81(\mathrm{~m}, 1 \mathrm{H}, \mathrm{Ar}-\mathrm{H}), 7.06-7.10$ (m, $5 \mathrm{H}, \mathrm{Ar}-\mathrm{H}), 7.42-7.53$ (m, 5H, Ar-H).

Entry 8 (2h). Yellow solid; m.p. $135-136^{\circ} \mathrm{C}$ FT-IR (KBr): $v_{\max }$ (in $\mathrm{Cm}^{-1}$ ) 3352, 1501, 1474; $1 \mathrm{H} \mathrm{NMR}\left(300 \mathrm{MHz}, \mathrm{CDCl}_{3}\right)$ : $\delta(\mathrm{ppm}): 7-7.25(\mathrm{~m}, 4 \mathrm{H}, \mathrm{Ar}-\mathrm{H}), 2.90-2.95(\mathrm{~d}, 1 \mathrm{H}, \mathrm{CH}), 3.90-$ $4.25\left(\mathrm{~m}, 2 \mathrm{H}, \mathrm{CH}_{2}\right), 3.5$ (br s, $\left.1 \mathrm{H}, \mathrm{NH}\right), 3\left(\mathrm{~s}, 2 \mathrm{H}, \mathrm{N}=\mathrm{C}-\mathrm{CH}_{2}\right)$, $2.5\left(\mathrm{~m}, 3 \mathrm{H}, \mathrm{N}=\mathrm{C}-\mathrm{CH}_{3}\right), 1.50-1.75\left(\mathrm{~s}, 6 \mathrm{H}, 2 \mathrm{CH}_{3}\right)$.

\section{Result and Discussion}

The XRD patterns of samples of MCM-22 zeolite are in agreement with those already reported [30-32]. All acquired $\mathrm{X}$-ray patterns identified the products as highly crystalline materials.

The FTIR spectrum of MCM-22 shows the presence of bands related to the symmetrical and asymmetrical stretching of $\mathrm{O}-\mathrm{H}$ band. The band at $786 \mathrm{~cm}^{-1}$ refers to external symmetrical stretching, whilst the band at $1237 \mathrm{~cm}^{-1}$ refers to external asymmetric stretching. The bands at 1095 and $1070 \mathrm{~cm}^{-1}$ correspond to internal asymmetric stretching and the bands at 594 and $550 \mathrm{~cm}^{-1}$ are attributed to the presence of double rings in MCM-22 structure. At $1626 \mathrm{~cm}^{-1}$ the band is ascribed to the angular deformation of the $\mathrm{N}-\mathrm{H}$ bond and water. The band at $449 \mathrm{~cm}^{-1}$ is related to the internal deformation of $\mathrm{O}-\mathrm{H}$ bands [33]. The band centered at $1384 \mathrm{~cm}^{-1}$ indicates the presence of amine functional group (HMI).

Initially the focus was on the synthesis of 1,5-benzodiazepine. The reaction was carried out using H-MCM-22 through a simple condensation reaction between OPDA and
TABLE 1: Effect of weight of H-MCM-22 on the synthesis of 1,5benzodiazepine.

\begin{tabular}{lcc}
\hline $\begin{array}{l}\text { Weight of catalyst } \\
\mathrm{mg}\end{array}$ & $\begin{array}{c}\text { Reaction time } \\
\text { Min. }\end{array}$ & $\begin{array}{c}\text { Yield } \\
\%\end{array}$ \\
\hline 50 & 60 & 30 \\
100 & 60 & 50 \\
150 & 60 & 87 \\
200 & 60 & 88 \\
\hline
\end{tabular}

Reaction conditions: Substrate: OPDA and acetone, reaction temperature: RT, solvent: acetonitrile.

acetone using acetonitrile as solvent at room temperature and the results are given in Table 2. The catalyst was found to be highly active, affording $87 \%$ isolated yield of 1,5 benzodiazepine in $60 \mathrm{~min}$. It should also be noted that when the reaction was conducted without any catalyst, the reaction does not occur. These results indicate that the acidity of the catalyst plays a critical role in this transformation and dictates the activity of the catalyst. The role of Brönsted acid site of H-MCM-22 catalyst on the formation of 1,5benzodiazepine and the reaction mechanism are clearly depicted in Scheme 2. As H-MCM-22 showed a much higher activity than other catalysts used in this study under the optimized reaction conditions, we have used H-MCM-22 for the remaining catalytic studies.

The synthesis of 1,5-benzodiazepines was also carried out over different amounts of H-MCM-22 at room temperature for $60 \mathrm{~min}$ and the results are given in Table 1. The weight of catalyst was increased between 50 and $200 \mathrm{mg}$. It was found that the yield increases from $30 \%$ to $87 \%$ with increase in the weight of the catalyst from 50 to $150 \mathrm{mg}$, respectively. This could be mainly due to the availability of huge number of acidic sites on the porous surface of H-MCM-22. It should be noted that the yield of the product remains constant with the further increase in the weight of the catalyst from 150 to $200 \mathrm{mg}$. Hence, we used the weight of the catalyst as $150 \mathrm{mg}$ for rest of the studies.

The excellent catalytic performance of H-MCM-22 in the synthesis of 1,5-benzodiazepine stimulated us to extend this process for the synthesis of various derivatives of benzodiazepines using various substituted OPDAs and a series of symmetrical and unsymmetrical ketones and the results are shown in Table 2. In all the cases, the reactions are highly selective and are completed within 1-3h. The catalyst showed excellent activity in all the cases, showing $65-87 \%$ isolated yield of the corresponding derivatives of 1,5-benzodiazepine. It was found that the catalyst showed superior performance with high yields in a relatively shorter reaction time than Ersorb-4 (E4), a clinoptylolite-type zeolite catalyst reported earlier [28]. It was interesting to see that E4 needed a high temperature and a longer reaction time conditions to achieve high isolated yield of the final product whereas H-MCM-22 was active even at room temperature. These findings reveal the superior nature of the studied catalyst in this transformation.

Chlorosubstituted OPDA and substituted ketones were also used with similar success to provide the corresponding 
TABLE 2: Synthesis of 1,5-benzodiazepines and its derivatives using H-MCM-22 through a condensation reaction between a series of OPDA and various ketones.

Entry Diamine Tetone

4<smiles>Nc1ccccc1N</smiles><smiles>O=C1CCCCC1</smiles><smiles>c1ccc(Nc2ccccc2NC2CCCCC2)cc1</smiles><smiles>Nc1ccc(Cl)cc1N</smiles><smiles>O=C1CCCCC1</smiles><smiles>Clc1ccc2c(c1)N=C1CCCC1C1(CCCC1)N2</smiles><smiles>Nc1ccc(Cl)cc1N</smiles><smiles>CCC(C)=O</smiles><smiles>CCC1=Nc2cc(Cl)ccc2NC(C)(CC)C1</smiles><smiles>Nc1ccc(Cl)cc1N</smiles><smiles>CC(=O)c1ccccc1</smiles><smiles>CC1(c2ccccc2)CC(c2ccccc2)=Nc2cc(Cl)ccc2N1</smiles><smiles>Nc1ccc(Cl)cc1N</smiles><smiles>CC(C)=O</smiles> 


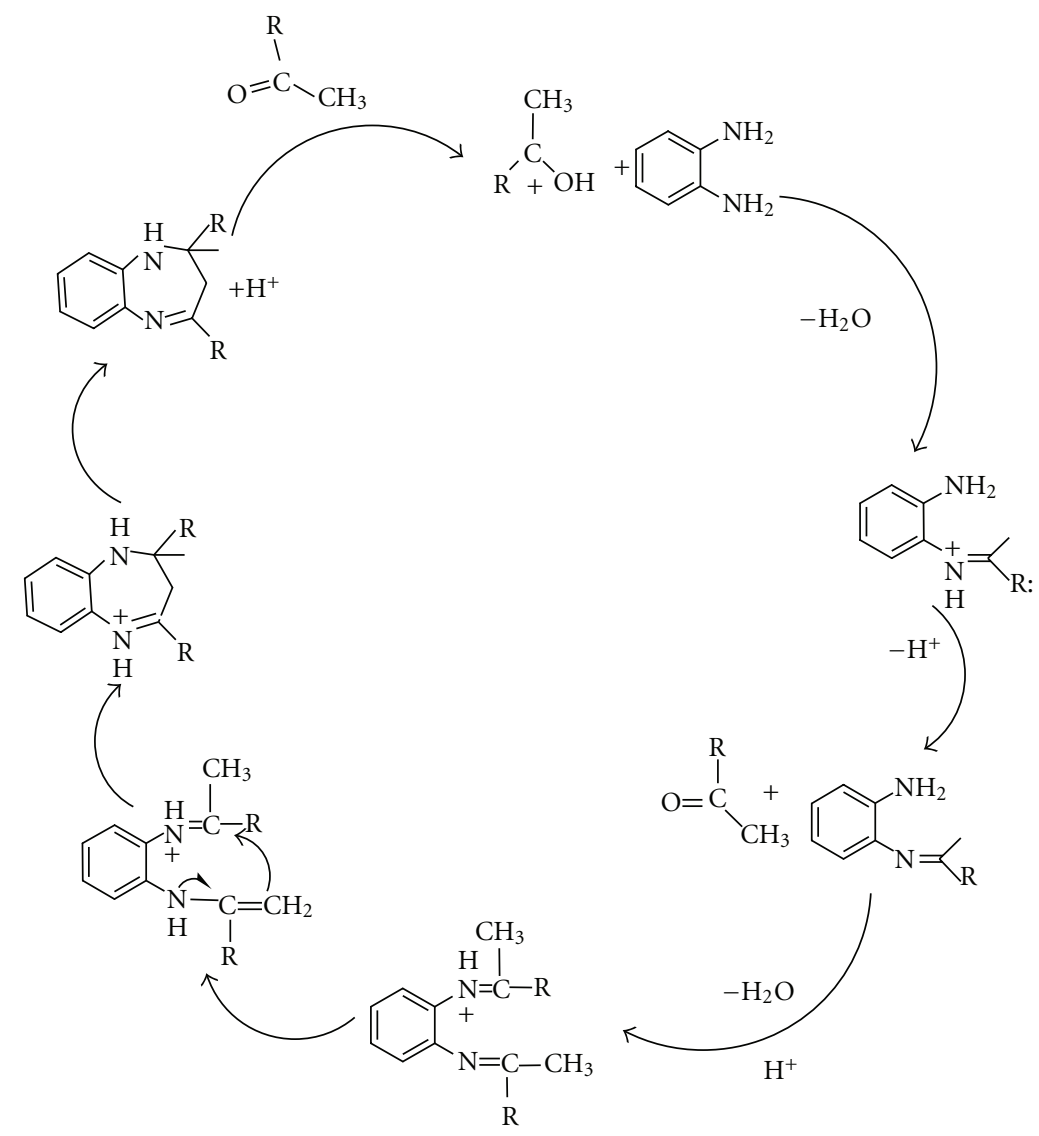

Scheme 2: Reaction mechanism of the synthesis of 1,5-benzodiazepines using H-MCM-22 catalyst at room temperature [29].

benzodiazepines in high yields, which are of much interest with regard to biological activity. Chlorosubstituted benzodiazepines in good yields in the presence of this catalyst were achieved easily.

It is also important to note that the workup of the reaction mixture is very simple. The catalyst can be filtered out easily and the solvent was evaporated. Recycling experiments were conducted to find out the stability of the catalyst after the reaction. The catalyst was easily separated by centrifuge and reused after activation at $500^{\circ} \mathrm{C}$ for 3-4 h. The efficiency of the recovered catalyst was verified with the reaction of OPDA and Ketone (Entry 1). Using the fresh catalyst, the yield of product (2a) was $87 \%$, while the recovered catalyst in the three subsequent recyclization gave the yields of $85 \%$, $81 \%$, and $75 \%$, respectively. The small reduction in the catalytic activity after three reaction cycles may be mainly due to the loss of catalyst or catalyst structure during the recovery process. These results reveal that the catalyst can be recycled several times without much loss in its activity.

\section{Conclusion}

The work reported has used H-MCM-22 catalyst for the synthesis of various benzodiazepines by using substituted OPDA and a series of symmetrical and unsymmetrical ketones at room temperature. This method is quite simple and selective.
The catalyst gave high isolated yield of the derivatives of 1,5-benzodiazepine in a shorter reaction time at room temperature and can be recycled several times. We strongly hope that the highly stable H-MCM-22 catalyst could pave the way for the production of 1,5-benzodiazepine and its derivatives and create the platform for the commercialization of the process by replacing the existing homogenous catalysts which suffered from various drawbacks such as corrosion, toxicity, waste production, and high cost.

\section{Acknowledgments}

Authors are highly thankful to DRDE Gwalior for financial assistance and SAIF Chandigarh for the characterization of the synthesized materials.

\section{References}

[1] J. R. de Baun, F. M. Pallos, and D. R. Baker, "5-furoyl- 2,2,4trimethyl-1,4-dihydro-1H-1,5-benzodiazepine as an anti-inflammatory agent," 1976, US Patent 3,978,227.

[2] J. R. de Baun, F. M. Pallos, and D. R. Baker, "5-furoyl- 2,2,4trimethyl-1,4-dihydro-1H-1,5-benzodiazepine as an antiinflammatory agent," Chemical Abstracts, vol. 86, p. 5498d, 1977.

[3] H. Schultz, Benzodiazepines, Springer, Heidelberg, Germany, 1982. 
[4] R. K. Smiley, Comprehensive Organic Chemistry, Pergamon, Oxford, UK, 1979.

[5] J. K. Landquist, Comprehensive Heterocyclic Chemistry, vol. 1, Pergamon, Oxford, UK, 1984.

[6] L. O. Randall and B. Kappel, "Pharmacological activity of some benzodiazepines and their metabolites," in Benzodiazepines, S. Garattini and E. Mussini, Eds., Raven, New York, NY, USA, 1973.

[7] R. C. Haris and J. M. Straley, "Lifting apparatus," 1968, US Patent $1,537,757$.

[8] A. M. El-Sayed, H. Abdel-Ghany, and A. M. M. El-Saghier, "A novel synthesis of pyrano(2,3-c)-, 1,3-oxazino(2,3 b)-,1, 2,4- triazolo(3,4-b)-, oxazolo(2,3-b)-, furano(3,2-c)-, and 3substituted- $(1,5)$ benzodiazepin-2-ones," Synthetic Communications, vol. 29, no. 20, pp. 3561-3572, 1999.

[9] J. X. Xu, H. T. Wu, and S. Jin, "Cycloaddition of benzoheteroazepine II reactions and conformations of cycloadducts on 1,5-benzothiazepines and 1,5-benzodiazepines with nitrile imine and nitrile oxides," Chinese Journal of Chemistry, vol. 17, no. 1, pp. 84-91, 1999.

[10] X. Y. Zhang, J. X. Xu, and S. Jin, "Cycloaddition of benzoheteroazepine reaction of 2,3-dihydro-lh-1,5-benzodiazepines with dichlorocarbene and stereo-structures of products," Chinese Journal of Chemistry, vol. 17, no. 4, pp. 404-410, 1999.

[11] K. Kim, S. K. Volkman, and J. A. Ellman, "Synthesis of 3substituted 1,4-benzodiazepin-2-ones," Journal of the Brazilian Chemical Society, vol. 9, no. 4, pp. 375-379, 1998.

[12] W. Reid and E. Torinus, "Über heterocyclische Siebenringsysteme, X. Synthesen kondensierter 5-, 7-und 8-gliedriger Heterocyclen mit 2 Stickstoffatomen," Chemische Berichte, vol. 92, no. 11, pp. 2902-2916, 1959.

[13] J. A. L. Herbert and H. Suschitzky, "Syntheses of heterocyclic compounds. part xxix. substituted 2,3-dihydro-1h-1,5benzodiazepines," Journal of the Chemical Society, pp. 26572661, 1974.

[14] H. R. Morales, A. Bulbarela, and R. Contreras, "New synthesis of dihydro-and tetrahydro-1,5-benzodiazepines by reductive condensation of o-phenylenediamine and ketones in the presence of sodium borohydride," Heterocycles, vol. 24, no. 1, pp. 135-139, 1986.

[15] D. I. Jung, T. W. Choi, Y. Y. Kim et al., "Synthesis Of 1,5benzodiazepine derivatives," Synthetic Communications, vol. 29, no. 11, pp. 1941-1951, 1999.

[16] M. S. Balakrishna and B. Kaboudin, "A simple and new method for the synthesis of 1,5-benzodiazepine derivatives on a solid surface," Tetrahedron Letters, vol. 42, no. 6, pp. 11271129, 2001.

[17] M. Curini, F. Epifano, M. C. Marcotullio, and O. Rosati, "Ytterbium triflate promoted synthesis of 1,5-benzodiazepine derivatives," Tetrahedron Letters, vol. 42, no. 18, pp. 31933195, 2001.

[18] X. Q. Pan, J. P. Zou, Z. H. Huang, and W. Zhang, "Ga(otf)3promoted condensation reactions for 1,5-benzodiazepines and 1,5-benzothiazepines," Tetrahedron Letters, vol. 49, no. 36, pp. 5302-5308, 2008.

[19] R. Kumar, P. Chaudhary, S. Nimesh, A. K. Verma, and R. Chandra, "An efficient synthesis of 1,5-benzadiazepine derivatives catalyzed by silver nitrate," Green Chemistry, vol. 8, no. 6, pp. 519-521, 2006.

[20] V. Sivamurugan, K. Deepa, M. Palanichamy, and V. Murugesan, "[(1)proline $]_{2} \mathrm{zn}$ catalysed synthesis of 1,5-benzodiazepine derivatives under solvent-free condition," Synthetic Communications, vol. 34, no. 21, pp. 3833-3846, 2004.
[21] P. Minothora, S. S. Julia, and A. T. Constantinos, "An efficient method for the synthesis of 1,5-benzodiazepine derivatives under microwave irradiation without solvent," Tetrahedron Letters, vol. 43, no. 9, pp. 1755-1758, 2002.

[22] W. Y. Chen and J. Lu, "Molecular iodine catalyzed one-pot synthesis of 1, 5-benzodiazepine derivatives under solvent-free conditions," Synlett, vol. 2005, no. 8, pp. 1337-1339, 2005.

[23] D. V. Jarikote, S. A. Siddiqui, R. Rajagopal, D. Thomas, R. J. Lahoti, and K. V. Srinivasan, "Room temperature ionic liquid promoted synthesis of 1,5-benzodiazepine derivatives under ambient conditions," Tetrahedron Letters, vol. 44, no. 9, pp. 1835-1838, 2003.

[24] B. M. Reddy, P. M. Sreekamth, and V. R. Reddy, "Modified zirconia solid acid catalysts for organic synthesis and transformations," Journal of Molecular Catalysis A, vol. 225, pp. 71-78, 2005.

[25] B. Kaboudin and K. Navaee, "Alumina/phosphorus pentoxide (app) as an efficient reagent for the synthesis of 1,5benzodiazepines under microwave irradiation," Heterocycles, vol. 55, no. 8, pp. 1443-1446, 2001.

[26] J. S. Yadav, B. V. S. Reddy, S. Praveenkumar, K. Nagaiah, N. Lingaiah, and P. S. Saiprasad, "Ag3pw12o40: a novel and recyclable heteropoly acid for the synthesis of 1,5benzodiazepines under solvent-free conditions," Synthesis, no. 6, pp. 901-904, 2004.

[27] M. A. Chari and K. Syamasundar, "Polymer (PVP) supported ferric chloride: an efficient and recyclable heterogeneous catalyst for high yield synthesis of 1,5-benzodiazepine derivatives under solvent free conditions and microwave irradiation," Catalysis Communications, vol. 6, no. 1, pp. 67-70, 2005.

[28] A. Hegedüs, Z. Hell, and A. Potor, "A simple environmentallyfriendly method for the selective synthesis of 1,5-benzodiazepine derivatives using zeolite catalyst," Catalysis Letters, vol. 105, no. 3-4, pp. 229-232, 2005.

[29] D. Shobha, M. A. Chari, S. T. Selvan et al., "Room temperature synthesis of 1,5-benzodiazepine and its derivatives using cage type mesoporous aluminosilicate catalysts," Microporous and Mesoporous Materials, vol. 129, no. 1-2, pp. 112-117, 2010.

[30] Y. J. He, G. S. Nivarthy, F. Eder, K. Seshan, and J. A. Lercher, "Synthesis, characterization and catalytic activity of the pillared molecular sieve MCM-36," Microporous and Mesoporous Materials, vol. 25, no. 1-3, pp. 207-224, 1998.

[31] S. L. Lawton, A. S. Fung, G. J. Kennedy et al., "Zeolite MCM49: a three-dimensional MCM-22 analogue synthesized by in situ crystallization," The Journal of Physical Chemistry, vol. 100, no. 9, pp. 3788-3798, 1996.

[32] S. B. C. Pergher, A. Corma, and V. Fornés, "Preparation and characterization of MCM-22 zeolite and its layered precursor," Química Nova, vol. 26, no. 6, pp. 795-802, 2003.

[33] A. Corma, C. Corell, and J. Pérez-Pariente, "Synthesis and characterization of the MCM-22 zeolite," Original Research Article Zeolites, vol. 15, no. 1, pp. 2-8, 1995. 

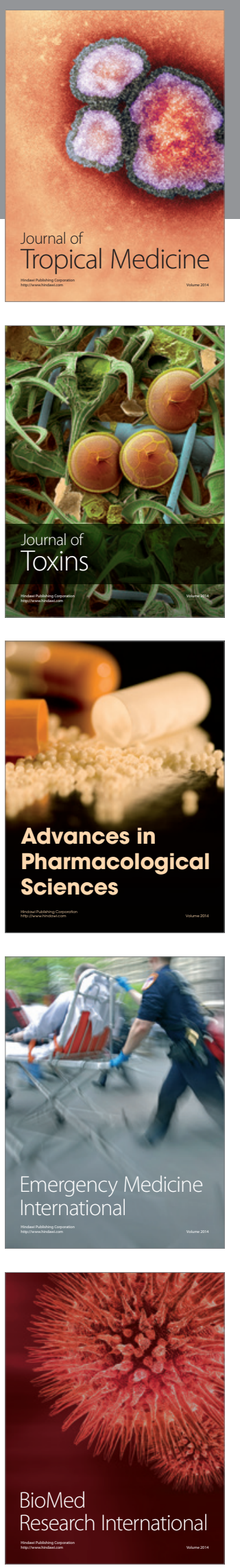
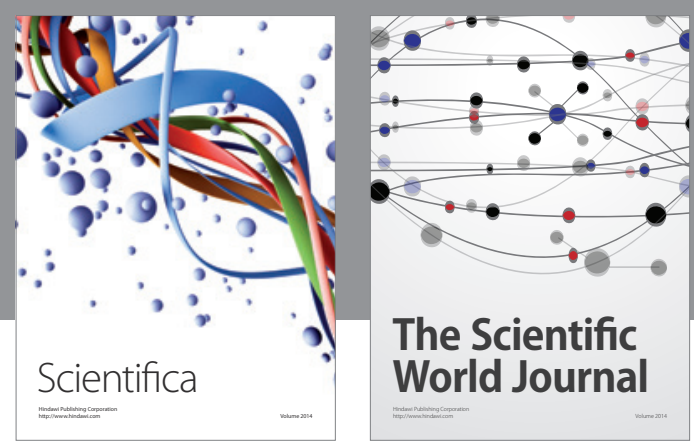

The Scientific World Journal
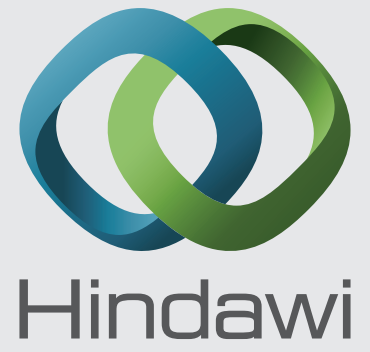

Submit your manuscripts at

http://www.hindawi.com
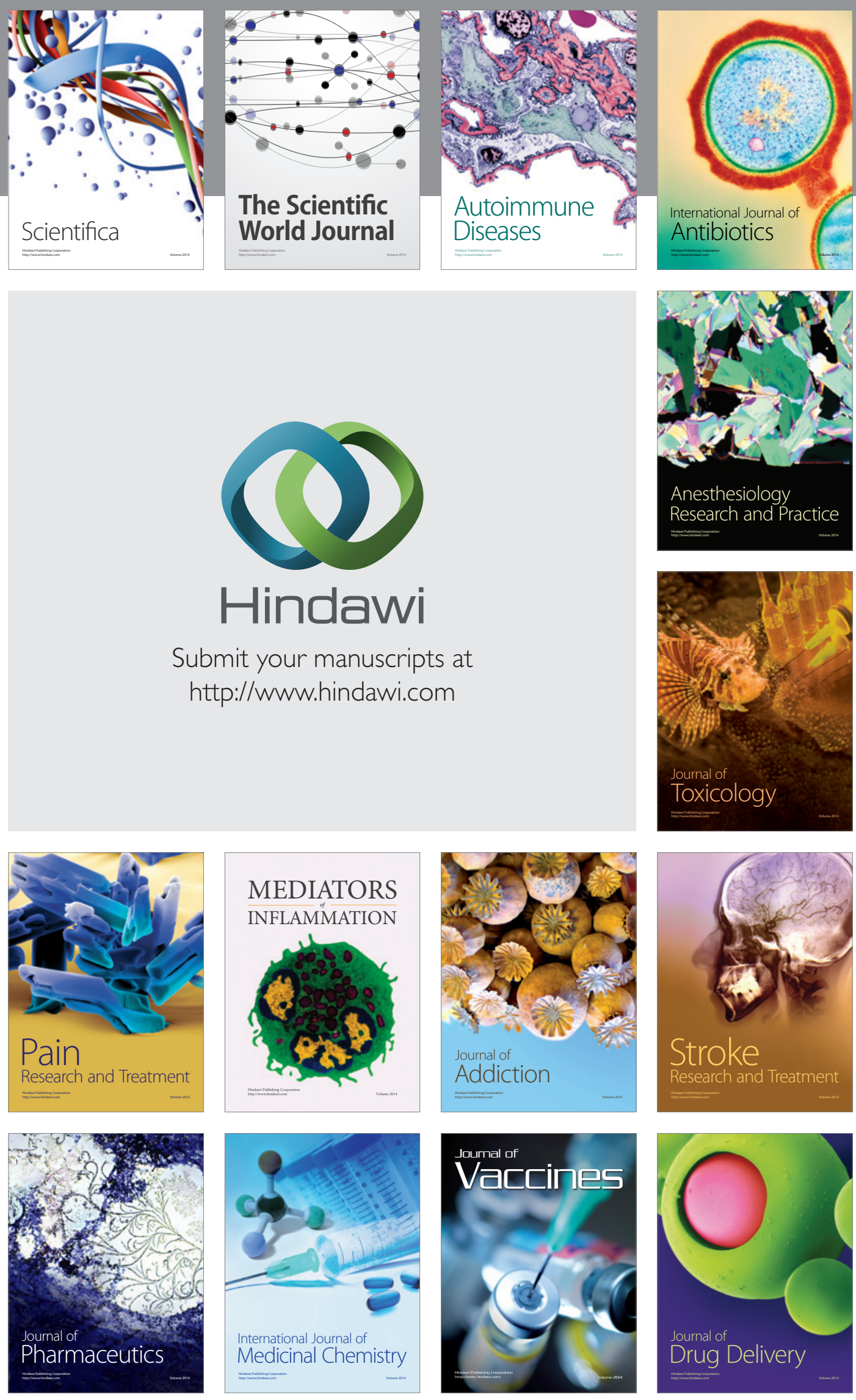